\title{
Recreational boats as potential vectors of marine organisms at an invasion hotspot
}

\author{
Ian C. Davidson ${ }^{1, *}$, Chela J. Zabin ${ }^{2}$, Andrew L. Chang ${ }^{2}$, Christopher W. Brown ${ }^{2}$, \\ Mark D. Sytsma ${ }^{1}$, Gregory M. Ruiz ${ }^{3}$ \\ ${ }^{1}$ Aquatic Bioinvasion Research \& Policy Institute, Environmental Sciences \& Management, \\ Portland State University \& Smithsonian Environmental Research Center, PO Box 751, Portland, Oregon 97207, USA \\ ${ }^{2}$ Marine Invasions Laboratory, Smithsonian Environmental Research Center, \\ Romberg Tiburon Center for Environmental Studies, 3152 Paradise Drive, Tiburon, California 94920, USA \\ ${ }^{3}$ Marine Invasions Laboratory, Smithsonian Environmental Research Center, PO Box 28, Edgewater, Maryland 21037, USA
}

\begin{abstract}
With more than 200 aquatic nonindigenous species (NIS), San Francisco Bay (California, USA) is among the world's most invaded harbors. Hard-substratum benthic (biofouling) organisms, which dominate NIS richness, have arrived primarily as a result of shipping and aquaculture activity over past centuries. To date there has been no assessment of the leisure craft vector in the Bay. We aimed to characterize (1) biofouling on boats' submerged surfaces and (2) boater behavior likely to affect the risk of NIS transfers. We used an underwater pole-cam, specimen collections, and a boater questionnaire to quantify the extent and composition of biofouling on recreational boats and to evaluate boater behavior at a subset of the Bay's marinas. Several NIS, already established within the Bay, were recorded from vessel hulls, including the bryozoans Bugula neritina, Membranipora chesapeakensis and Watersipora sp., the ascidians Botrylloides violaceus, Styela clava and Ciona intestinalis, the polychaete Ficopomatus enigmaticus, and the sponge Clathria prolifera. Only $16 \%$ of questionnaire respondents had traveled to sites outside the Bay in the previous $12 \mathrm{mo}$. Frequency of hull painting and cleaning varied substantially, but we did not find strong patterns of biofouling extent associated with hull husbandry or boat usage. The potential for within-Bay and coastwise regional spread of NIS is high, and recreational boats probably interact in close proximity to other vectors (e.g. commercial ships), causing a ratchet effect of vector events; however, there remains a gap in understanding the levels and condition of biofouling on transient boats. Transient vessels from San Francisco Bay and other West Coast sites should be the focus of future studies to evaluate the extent to which organisms are being transferred among bays and how vector management could be applied to prevent NIS transfers and impacts.
\end{abstract}

KEY WORDS: Biofouling $\cdot$ Bioinvasions $\cdot$ Nonindigenous species $\cdot$ Recreational boats $\cdot$ Vector Resale or republication not permitted without written consent of the publisher

\section{INTRODUCTION}

Despite its fundamental contribution to the invasion process, the initial transfer stage of invasions is understudied in terrestrial and aquatic systems (Puth \& Post 2005) and excluded in some invasion frameworks where the dispersal stage is disregarded (e.g. Cadotte et al. 2006). In marine systems, ballast water, ship biofouling, mariculture transfers, ornamental release, biocontrol, and canals are widely acknowledged historical and contemporary human vectors of coastal species (Carlton 1985, Ruiz et al. 2000, Galil 2008). However, direct studies of vector processes are uncommon, and there are gaps in understanding the interaction between source populations and the human activities that cause range expansions by nonindigenous species (NIS).

Most marine NIS worldwide have been introduced inadvertently, and assigning a vector for each NIS transfer is often not straightforward for several reasons. 
First, vectors are simply unknown for 'cryptovectic' species. Second, 'polyvectic' species have life stages that can be associated with numerous vectors acting simultaneously in time and space, such that the importance of individual transfer mechanisms to each introduction cannot be estimated (Carlton \& Ruiz 2003, Fofonoff et al. 2003). Third, even within a vector, there are sometimes several options for species transfer that can operate differently. This is exemplified by biofouling species transfers on vessels. Commercial ships, recreational boats, and other vessels (such as decommissioned ships, fishing vessels, floating dry docks, towed rigs, and research vessels) transfer a diversity of sessile species and associated motile organisms over a range of geographic scales (Chilton 1910, Foster \& Willan 1979, DeFelice 1999, Coutts \& Taylor 2004, Floerl \& Inglis 2005, Minchin et al. 2006, Davidson et al. 2008, Lee \& Chown 2009). Each vessel category differs in vector tempo, because the behaviors governing activities in each vessel category affect the size, rate, speed, duration, and timing of biota transfers.

Large commercial vessels (ships rather than boats) received greater attention historically (e.g. Visscher 1928, WHOI 1952, Gollasch 2002), but recreational craft have come under greater scrutiny in the last decade. Recent studies of recreational boats have characterized organism transfers in a few regions of the world including New Zealand, northeastern Australia, the east coast of North America, and European coasts (Floerl \& Inglis 2005, Floerl et al. 2005a,b, Ashton et al. 2006, Minchin et al. 2006, Mineur et al. 2008, Darbyson et al. 2009, R. Osman pers. comm.). Other studies of NIS incursions of bays without commercial ports have also provided indirect evidence for NIS transfers by recreational boats (Carlton 1979, Wasson et al. 2001, Cohen et al. 2005).

Movement of recreational craft within and among bays and estuaries provides a degree of connectivity that has largely gone unappreciated. Boat movements create a potentially important mechanism for humanmediated species transfers (and secondary spread after initial colonization) from major harbors to numerous adjacent bays that do not receive commercial vessels. In addition, unaccounted-for transfers of species may undermine the efficacy of measures taken by commercial vessels to prevent the coastwise spread of NIS (for example, through coastal ballast water management; Simkanin et al. 2009).

The relative importance of species transfers by recreational craft may vary greatly among geographic locations, based on the numbers of vessels, movement patterns, and the extent of invasions. Recreational vessels may be especially important in highly invaded estuaries, such as San Francisco Bay (SF Bay), California (USA), where (1) 231 established NIS have been recorded; (2) a large proportion of these NIS are biofouling organisms associated with hard substrata; and (3) over 150000 boats are registered to owners in counties bordering the shores of the Bay (Cohen \& Carlton 1998, California State University Sacramento Foundation 2002, Ruiz et al. 2009). To our knowledge, recreational vessel hulls have not been sampled-and the movements of these boats are not well understood - on the US West Coast, even though marinas are often foci for NIS surveys (especially for biofouling communities).

The aim of this study, therefore, was to explore the links between biofouling on submerged surfaces of recreational boats and the vector activity of boaters in SF Bay. Commercial ships are considered among the primary vectors for initial invasions to the Bay, but little is known about the influence of smaller boats on spreading these species within the Bay and to adjacent sites on the outer coast. As a first step in characterizing this vector on the US West Coast, we conducted hull sampling at a subset of marinas in SF Bay and distributed a questionnaire to boaters to evaluate (1) extent and composition of biofouling on vessels and (2) hull maintenance and voyage history patterns among boaters. We also evaluated a ranking system developed by Floerl et al. (2005a) and assigned ranks to over 1200 boats. We used these data to categorize recreational vessels according to biofouling levels, vessel behavior, and risk of NIS spread.

\section{MATERIALS AND METHODS}

Hull sampling. Sampling of recreational vessels was conducted at 6 marinas, encompassing a gradient of salinity, in SF Bay during September 2007. The marinas were as follows: Antioch in the San Joaquin Delta; Benicia, near the Carquinez Strait; Loch Lomond, in San Rafael in the North Bay; Berkeley, in the Central East Bay; San Leandro, on the east side of South Bay; and Oyster Point, at the city of South San Francisco on the west side of South Bay (Fig. 1). Antioch marina was most influenced by freshwater, having annual salinities ranging from 0 to 2 psu. Hull surveys of 12 vessels, chosen based on permission by boat owners, were conducted at each of the 6 marinas ( $n=72$ boats) using an underwater pole-cam (UPC; $2.9 \mathrm{~mm}$ wide-angle lens, Wadeware Technology). Based on casual observations of general hull condition, the 12 vessels surveyed were likely to be representative of the general pool of vessels moored in the marina at the time of sampling (i.e. the 12 boats were not obviously skewed toward a certain level of fouling). The UPC is a camera unit within a waterproof housing that is attached to a telescopically extendable pole and connected via wiring to a battery box and monitor with recording device. On 


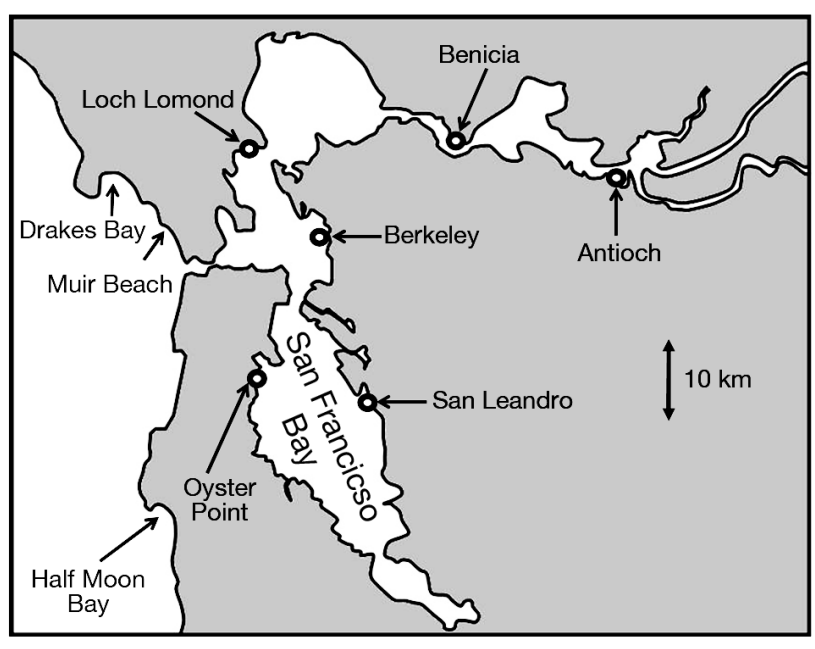

Fig. 1. Marinas in San Francisco Bay, California (USA), used for sampling recreational boat hull biofouling. A gradient of increasing salinity occurs from Antioch marina ( 0 to $2 \mathrm{psu}$ ) to the mouth of the Bay (33 to $35 \mathrm{psu}$ )

each vessel, the UPC was used to gather photoquadrat video images by placing the camera frame against the hull. These were subsequently captured as still images of replicate photo-quadrats of $100 \mathrm{~cm}^{2}$ of hull surface area. Sampling was stratified by depth, with 8 replicates taken at each of 2 horizontal transects just below the waterline and at the hull bottom (16 replicates per boat). We also used the UPC to collect video footage of the heterogeneous surfaces of stern appendages (e.g. rudder, propeller, struts) for assessment of diversity and qualitative comparison with hull transects. The stern areas surveyed were smaller than hull transects ( 25 to $40 \%$ of hull areas) but were more heterogeneous surfaces.

Fouling cover on each replicate photo-quadrat image was quantified using a point count method with a grid of 100 dots superimposed. Eighteen categories were used for the cover estimates, comprising 17 coarse taxonomic (functional) groups and 1 category of paint/hull surface (Table 1). This provided a data matrix of organism percent cover of 1152 samples for 72 boats at 6 marinas. Additionally, the number of biofouling groups (17 taxa) observed in the video footage of each vessel's stern appendages was recorded and used for richness comparisons with hull transects. Throughout the text, 'taxa' refers to the biofouling categories. Because taxa were defined conservatively to avoid misidentification from UPC images, we also collected qualitative samples of species from vessel hulls for dock-side species-level identifications of NIS recorded from hulls.

Questionnaires to boat owners. We developed a questionnaire to ascertain patterns of vessel husbandry and recent voyage history of boaters in SF Bay. This was similar in scope to the questions posed by Floerl \& Inglis (2005) in their study in northeastern Australia. The questionnaire consisted of 6 multi-part questions directed at boat owners to discern their vessel's characteristics, their boat maintenance practices, and their boat usage (Table 2). Questionnaires were distributed to boaters using 4 different methods:

Table 1. Categories used for point count percent cover estimates of biofouling on recreational vessels. We used 17 readily distinguishable taxa (functional groups) and 1 category of paint/hull surface (bare space) to analyze photo-quadrats

\begin{tabular}{|c|c|}
\hline Category & Description \\
\hline Paint/hull (bare space) & Paint or hull surface without evidence of fouling coverage (including biofilm) \\
\hline Slime/biofilm & $\begin{array}{l}\text { Covering of microalgae and other particles that can vary in thickness but appears slimy, is easily } \\
\text { removed, and is characteristically scraped by the scale bar attached to the front of the camera }\end{array}$ \\
\hline Diatom algae & $\begin{array}{l}\text { Brownish-green clumps or strands of 'diatom algae' that are easily removed and are often several } \\
\text { centimeters thick }\end{array}$ \\
\hline Filamentous green algae & Green grassy- or mossy-looking algae such as Enteromorpha spp. ${ }^{a}$ or Cladophora spp. \\
\hline Green macroalgae & Large chlorophytes such as Ulva and Codium spp. \\
\hline Brown macroalgae & Large phaeophytes such as fucoids, kelps, and Sargassum \\
\hline Red encrusting & Encrusting rhodopytes such as Lithothamnion and Lithophyllum spp. \\
\hline Red macroalgae & Large non-encrusting rhodophytes such as Chondrus and Palmaria spp. \\
\hline Barnacles & Acorn or goose-neck barnacles \\
\hline Tubeworms & Tubiculous polychaetes such as serpulid or spirorbid worms \\
\hline Hydroids & Hydrozoans \\
\hline Bryozoans & Encrusting or erect/arborescent bryozoans such as Watersipora and Bugula \\
\hline Anemones & Anthozoans \\
\hline Bivalves & Mollusks such as mussels or oysters \\
\hline Solitary ascidians & Solitary tunicates such as Styela and Ciona \\
\hline Colonial ascidians & Colonial tunicates such as Botryllus, Botrylloides, and Didemnum \\
\hline Sponges & Porifera such as Halichondria \\
\hline Other & Mobile taxa, including amphipods, isopods, and decapods, or any unidentifiable taxa \\
\hline
\end{tabular}


Table 2. Summary of information requested from San Francisco (SF) Bay, California (USA), boat owners. Questionnaires were distributed to boaters and marinas to gather information on 6 topics related to vessel particulars, boat usage, and maintenance. Where possible, questions were posed such that answers could be given in the form of multiple choice tick-box answers

\begin{tabular}{|c|c|c|}
\hline Item no. & Topic & Specific information requested \\
\hline 1 & Type of craft & Whether the boat was a sail boat/yacht, motor boat, or other type of vessel \\
\hline 2 & Home marina & Name of the marina at which the owner's boat was moored \\
\hline 3 & Antifouling paint & $\begin{array}{l}\text { Date of most recent paint application } \\
\text { Type of paint or specific product used }\end{array}$ \\
\hline 4 & Manual hull cleaning & $\begin{array}{l}\text { Whether the boat been cleaned since the last paint application } \\
\text { Number of times it had been cleaned since painting } \\
\text { Date of the most recent cleaning } \\
\text { Location of the most recent cleaning (e.g. in-water at a marina, on a trailer at a slip) }\end{array}$ \\
\hline 5 & $\begin{array}{l}\text { Voyage information/ } \\
\text { vessel usage }\end{array}$ & $\begin{array}{l}\text { Number of trips taken in the last } 12 \text { mo } \\
\text { Destinations of trips (e.g. inside SF Bay, outside SF Bay, by trailer) } \\
\text { Duration of trips }\end{array}$ \\
\hline 6 & Hull survey participation & Whether the owner would permit a hull survey using the underwater pole-cam \\
\hline
\end{tabular}

(1) pick-up and drop-off boxes at marina offices; (2) direct mailing in cooperation with marinas; (3) direct distribution to boaters at marinas during sampling periods; (4) via the internet. Questionnaires were returned to us directly, by fax, by mail, and by email. We were unable to attempt a measure of response rate because of different approaches to dissemination by each marina (i.e. we could not determine how many questionnaires were actually delivered to boaters).

Level of fouling (LoF) surveys. At each of the 6 marinas, all vessels moored on the day of sampling were assessed using the LoF ranking system developed by Floerl et al. (2005a). This method involves designating a rank of biofouling to each vessel based on an assessment of visible biofouling from above the water. The ranking system ranges from 0 , for a vessel with no visible biofouling below the waterline, to 5, which includes vessels with very heavy biofouling (>41\% cover) dominated by a diverse assemblage of macroalgae and/or macrofaunal species (see Floerl et al. 2005a). A total of 1265 vessels were assigned a LoF rank across the 6 marinas surveyed.

Data analysis. A data matrix of percent cover estimates (8 replicates $\times 2$ transects $\times 12$ vessels $\times 6$ marinas) was explored using multivariate analyses to test for patterns in fouling (18 categories) across the 72 vessels surveyed. Data from stern appendages were also used to evaluate the compositional differences among vessel locations (waterline, bottom depths, and stern appendages) and among marinas. The analysis of similarities (ANOSIM) test was used to assess compositional differences among boats at marinas using the PRIMER program (version 5, Primer-E). Univariate tests were performed on biofouling extent and richness data. Richness and extent data violated the assumptions of normality and homogeneity of variance (Anderson-Darling and Levene tests, all $\mathrm{p}<0.001$ ).
Transforming the data did not resolve these issues. Therefore, non-parametric (Kruskal-Wallis, K-W) tests were used to evaluate differences in taxonomic richness and percent cover of macrofouling (algae and invertebrates combined) among marinas and between transect depths. The $\mathrm{K}-\mathrm{W}$ test is a non-parametric equivalent of the 1-way analysis of variance (ANOVA, a 'rank' test) that makes no assumptions about homogeneity of variance and normal distributions (Dytham 2003). Where correlations were performed, the nonparametric Spearman's rank-order correlation was used.

The responses to questionnaires regarding hull maintenance (age of antifouling paint, time since last manual cleaning, products and methods used by boaters) and boat use (number of recent trips, destinations, durations) were tabulated and used to describe some general patterns among SF Bay boaters. A subset of the vessels sampled using the UPC had matching questionnaire data (53 of 72 vessels sampled). We examined age of antifouling paint, time since last cleaning, and number of voyages in the past 12 mo to determine if any relationship existed between these variables and biofouling on these vessels. Finally, we tested correlations between LoF ranks and biofouling level on 72 vessels sampled quantitatively. We then compared frequency of LoF ranks among marinas and between the present study (1265 boats) and comparable ones in New Zealand and Scotland (Floerl et al. 2005a, Ashton et al. 2006).

\section{RESULTS}

\section{Biofouling extent and richness}

Only 1 of the 72 vessels examined using the UPC had no detectable biofouling. Another 14 had no macro- 
fouling species (biofilm only), but all other boats had either macroalgae or macrofauna on hull surfaces. There were significant differences among marinas in percent cover of macrofouling (algae and invertebrates) on boats (K-W test, $H=19.24, \mathrm{p}<0.01$ ). Boats in Antioch marina had the least biofouling (mean of $52.5 \%$ bare space), which coincided with a complete absence of macroinvertebrate biofouling coverage (Fig. 2). The highest mean percent cover of biofouling $(80 \%)$ was found on boats at Oyster Point marina, although most of this was slime/biofilm (71\% on average) rather than macrofouling. Vessels at Berkeley marina had the highest percent cover of macroalgae and invertebrates (Fig. 2), and the highest cumulative richness (16 of 17 morpho-taxa were recorded on boats at Berkeley). Transect depth was also a significant factor for differentiating biofouling extent on boats (K-W test; $H=5.75, \mathrm{p}<0.05$ ), with lesser cover near the waterline.

Taxa richness on individual boat hulls (combined transects) ranged from 0 to 14 , but richness did not differ significantly between transects $(H=2.71, \mathrm{p}>0.05)$. As with biofouling extent, however, there were significant differences in richness among marinas $(H=41.59$,

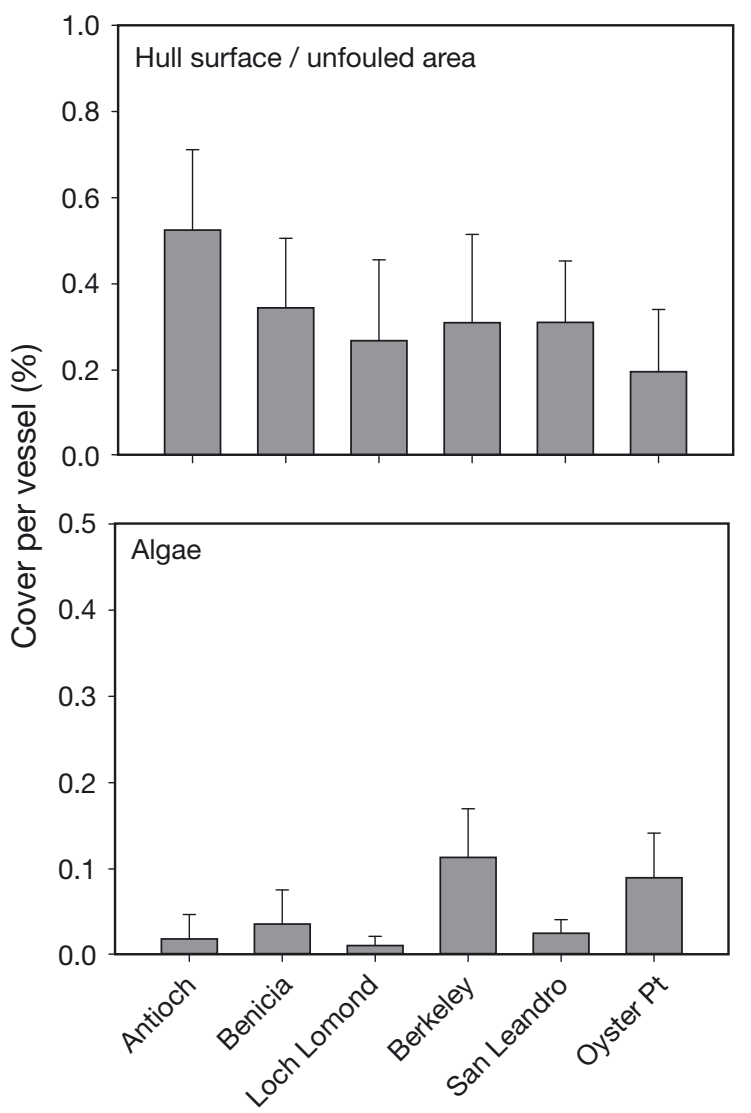

$p<0.001)$. Vessels in Berkeley and Antioch marinas had the highest and lowest mean taxa richness, respectively (Fig. 3). Slime/biofilm was the most widely occurring biofouling category among the 72 vessels sampled, followed by filamentous green algae and bryozoans. All 17 taxa were found on at least 1 vessel, with red encrusting algae and brown macroalgae occurring on just 1 vessel each. Bivalves were only recorded on 1 vessel, and only on stern appendages. Bottom-depth hull transects had a lower frequency of algal taxa compared to waterline transects (4 times as many boats had algae at the waterline compared to the deeper transect). There were several taxa, most notably solitary ascidians, sponges, and red macroalgae, that occurred far more frequently on stern appendages than on hull surfaces. For example, sponges were recorded twice as often during stern surveys compared to hull surveys (23 versus 11 ).

Multivariate analyses revealed no distinct clustering of vessels in terms of biofouling composition among marinas or between transect depths. This was somewhat unexpected given the salinity differences among marinas and the differences in algal occurrence between the illuminated sides of vessels versus the dark-
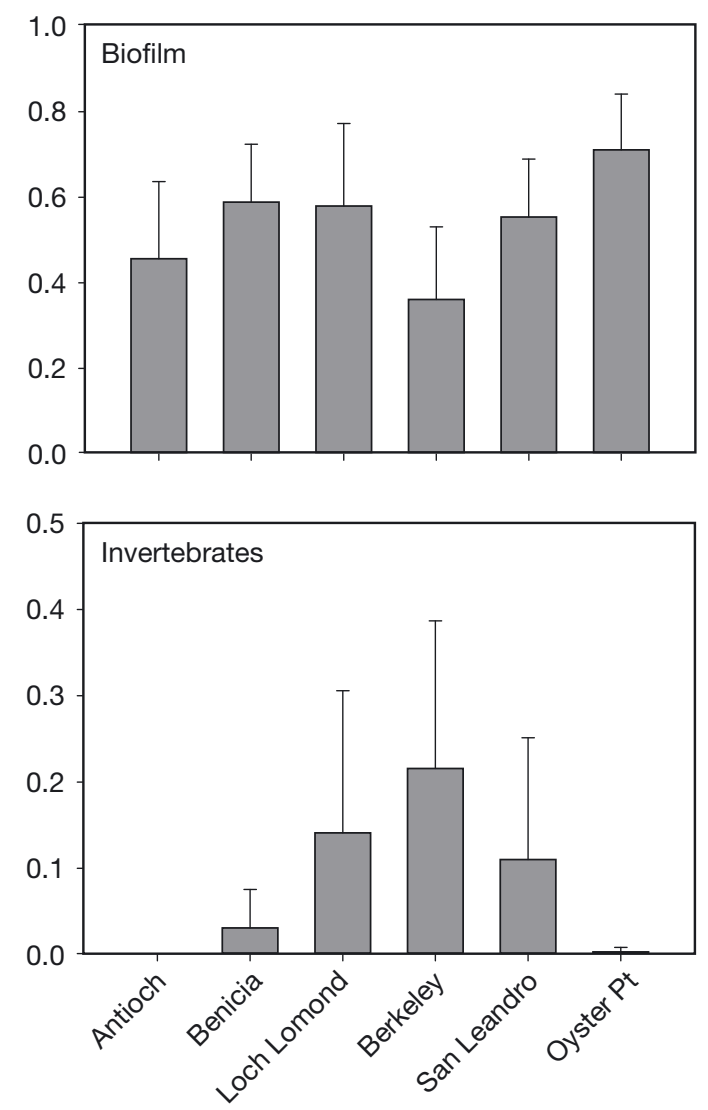

Fig. 2. Biofouling extent among marinas. Mean percent cover (+95\% CI) of unfouled hull surface, slime/biofilm, algal taxa, and faunal taxa are shown for vessels at each of the 6 marinas $\left(n=12\right.$ vessels marina $\left.{ }^{-1}\right)$. Note the change in scale of the $y$-axis between upper and lower plots 


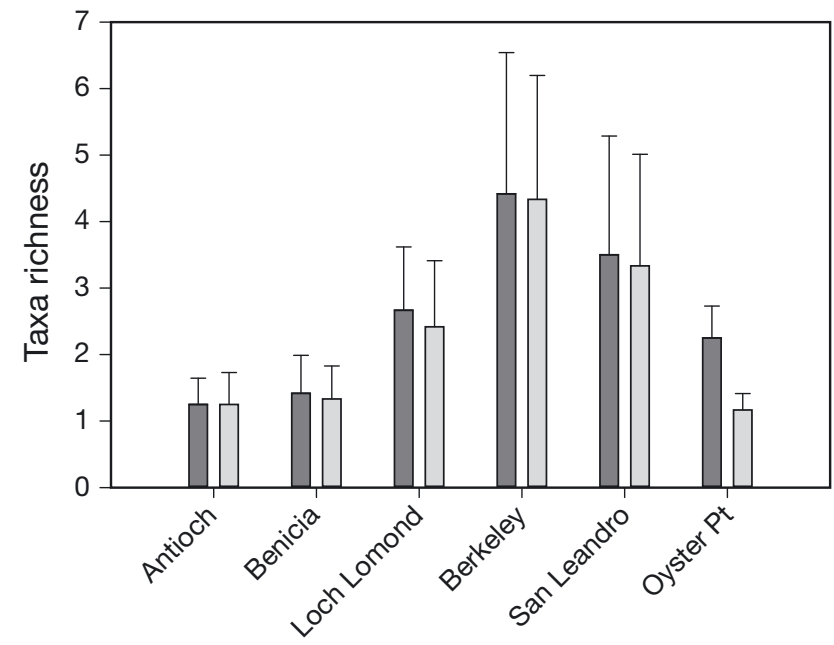

Fig. 3. Biofouling taxa richness among marinas. The mean taxa richness $( \pm 95 \% \mathrm{CI})$ per hull transect is plotted for each marina $\left(\mathrm{n}=12\right.$ vessels marina $\left.{ }^{-1}\right)$. Dark gray bars: waterline transects; light gray bars: bottom-depth transects

ened undersides of hulls. The limited number of taxa used in this study (17) may explain some of the homogeneity, and a finer taxonomic analysis would probably reveal greater distinction among marinas. ANOSIM tests confirmed that marinas and transect depths were not significant factors for differentiating biofouling composition among vessels (all $\mathrm{R}<0.2$ ). Substantial cover of bare space and biofilm (Fig. 2) among all marinas also contributed to this result.

There were, however, some notable contrasts among marinas in taxa occurring on boats (Fig. 4). Antioch marina was the only location at which macrofaunal species were not observed on boats. Bryozoans occurred on hulls at the other 5 marinas. Boats at Berkeley marina, the most taxa-rich site, harbored every taxon listed except bivalves, which was the only taxon not recorded on any hull surface throughout the study (bivalves were recorded at Oyster Point marina on propeller shafts only). Solitary ascidians and sponges occurred on boats at Loch Lomond, Berkeley, and San Leandro marinas. Colonial ascidians were found on hulls in Berkeley marina only.

On-site identification of specimens at dock side revealed that several marine NIS that are established in SF Bay were present on the hulls of sampled vessels. The bryozoans Bugula neritina, Membranipora chesapeakensis, and Watersipora sp. were recorded at high density on some boats in 4 marinas (over 40 colonies per vessel). Ciona intestinalis, a non-native solitary ascidian, occurred in dense aggregations of hundreds of individuals per boat among heavily fouled boats at Berkeley and Loch Lomond marinas. The invasive club tunicate Styela clava was also encountered, but only on a handful of boats and at an order of magnitude lower density than $C$. intestinalis (10s of individuals). The non-native colonial encrusting tunicate Botrylloides violaceus was recorded occasionally on hulls and stern appendages. The invasive polychaete Ficopomatus enigmaticus was found on very heavily fouled vessels. The distinctive erect branching sponge Clathria prolifera was encountered on hulls of heavily fouled recreational boats in marinas where it was also conspicuous on nearby docks (e.g. San Leandro marina). In contrast, some notable marine NIS that were highly visible and very prevalent on marina docks, including the green algae Codium fragile subsp. tomentoides, were not recorded on hulls of vessels, including the most heavily fouled boats.

\section{Boat maintenance and vessel movements}

In total, 221 questionnaires were returned from boaters who used 14 different marinas throughout the SF Bay area. Sail boats/yachts were owned or operated by $67 \%$ of respondents, and $30 \%$ had motor boats (3\% did not specify vessel type). Thirty-seven percent

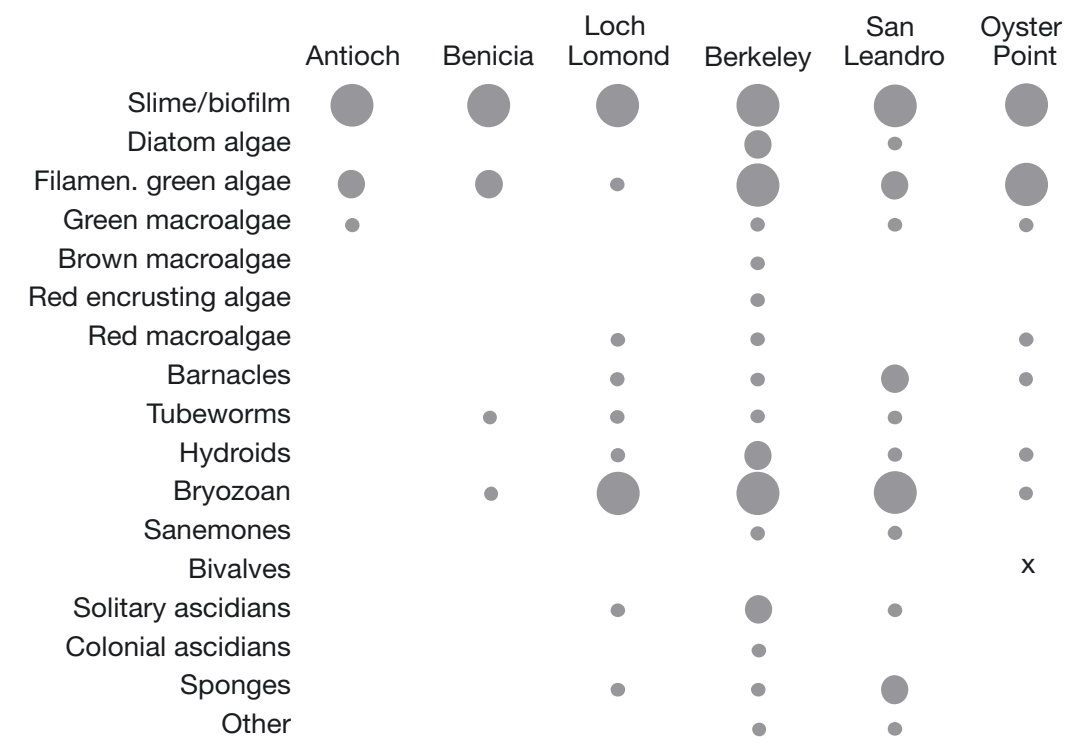

Fig. 4. Occurrence of taxa on vessel hulls among marinas. The occurrence of 17 taxa is plotted for each of 6 marinas with dot size (small, medium, large) representing rare, frequent, and abundant occurrence of the taxon across vessels, respectively. The absence of a dot represents the absence of a taxon at that marina. Taxa were considered rare if they occurred on 4 or fewer vessels, frequent if they were on 5 to 8 vessels, and abundant if they were on 9 or more vessels. $\mathrm{X}$ : occurrences of organisms recorded only on stern appendage surfaces (not on hull transects). Filamen.: filamentous 
of respondents reported that their most recent paint application occurred within the year prior to sampling (September 2007), while $56 \%$ of boats had bottom paints older than 12 mo. Over $50 \%$ of respondents did not know (or did not provide) the product name or type of paint used on their vessel, while $44 \%$ reported the use of copper-based antifouling paints. At least 1 manual hull cleaning since the last application of antifouling paint was reported by $58 \%$ of boaters, and 97 of these $(75 \%)$ had cleaned more than once. Seventy percent of the boats with antifouling paint aged more than 1 yr had been cleaned manually within the last 12 mo. Manual hull cleaning was primarily done in-water at marinas (91\% of reported cleaning events), with just $7 \%$ of boaters carrying out manual cleaning on a trailer or sling on land. Responses also indicated that the most active boaters in terms of trips taken tended to manually clean their vessel more regularly and recently (Fig. 5a).

Questionnaire responses revealed that 38\% of boaters took up to 10 trips within the Bay in the last year and $16 \%$ took more than 20 trips (Fig. 5b). Boat trips occurred overwhelmingly within the Bay, with $76 \%$ of respondents reporting that no trips outside of SF Bay had been taken in the past 12 mo (Fig. 5c). Nearly $14 \%$ of boaters reported taking up to 5 trips outside the Bay, but less than $2 \%$ took more than 5 trips outside of the Bay (8\% provided no response on voyages). In total, 109 trips were reported to destinations outside of SF Bay. A substantial majority (74\%) of these trips were to destinations along the Pacific coast of central California within $\sim 50 \mathrm{~km}$ of the Golden Gate Bridge, including Half Moon Bay to the south and Muir Beach and Drakes Bay to the north. There were 11 trips reported to Monterey Bay, 3 to Bodega Bay, and 6 to southern California (including San Diego and Catalina Island). The only in-water voyage outside of California involved 1 sailing trip to Chile. Four boaters reported taking their boat to other regions overland by trailer, including Santa Barbara, Puget Sound, British Columbia (Port Hardy), and 1 cross-country trip to South Carolina and back. A majority of the trips outside of SF Bay were quite short; the most commonly reported duration of these trips was $1 \mathrm{~d}(51 \%)$, while $19 \%$ of trips were of $5 \mathrm{~d}$ or longer duration.

For the subset of vessels for which we had percent cover data and questionnaire answers, we found no relationships between time since maintenance (age-ofpaint or time since last manual cleaning) and biofouling cover. Macrofouling cover tended to increase in relation to age of paint, but there was no significant correlation (Spearman's $r=0.177, \mathrm{p}>0.05$; Fig. 6a). Although antifouling paints applied $\geq 60$ mo prior to sampling were heavily fouled, there was substantial variation among vessels with paints that were $<30$ mo
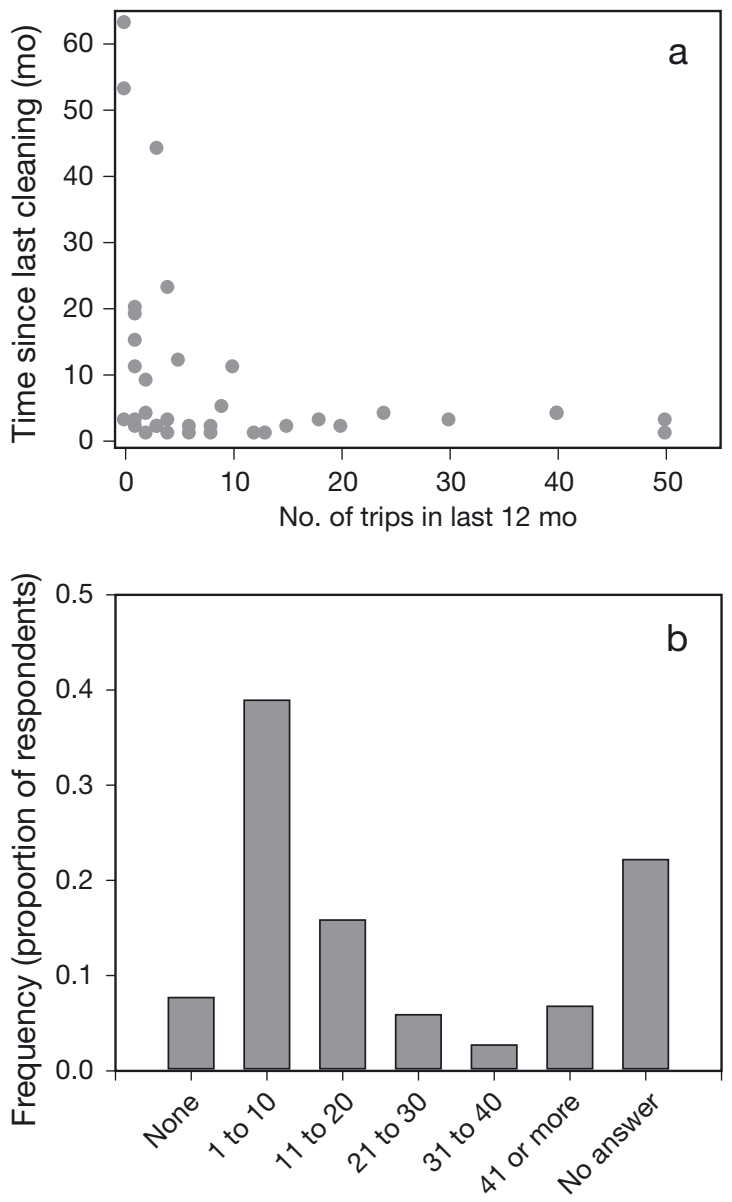

No. of boat trips within SF Bay

No. of boat trips outside SF Bay

C

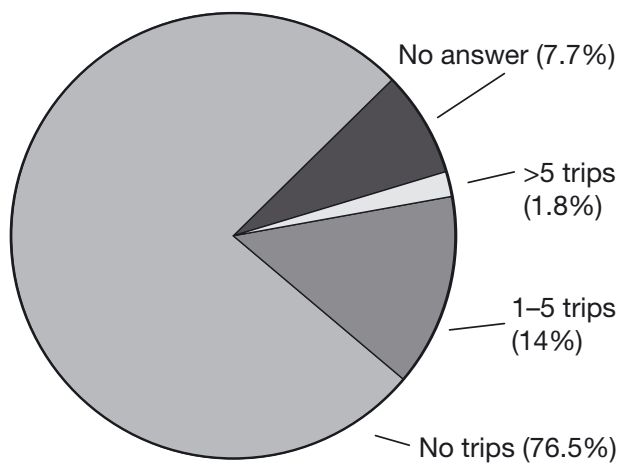

Fig. 5. Patterns of boat usage and maintenance. (a) Boat usage (number of trips) with time since last cleaning (in months). (b) Frequency (proportion of respondents) of boaters reporting their voyage history over a 12 mo period. (c) Percentage of respondents who reported trips outside of San Francisco Bay by boat (not on trailers) in the previous 12 mo

old. Time since cleaning did not correlate significantly with biofouling cover $(\mathrm{r}=0.054, \mathrm{p}>0.05$; Fig. 6b). This was primarily because vessels that were reported to have been recently cleaned ( $<6$ mo previously) had 

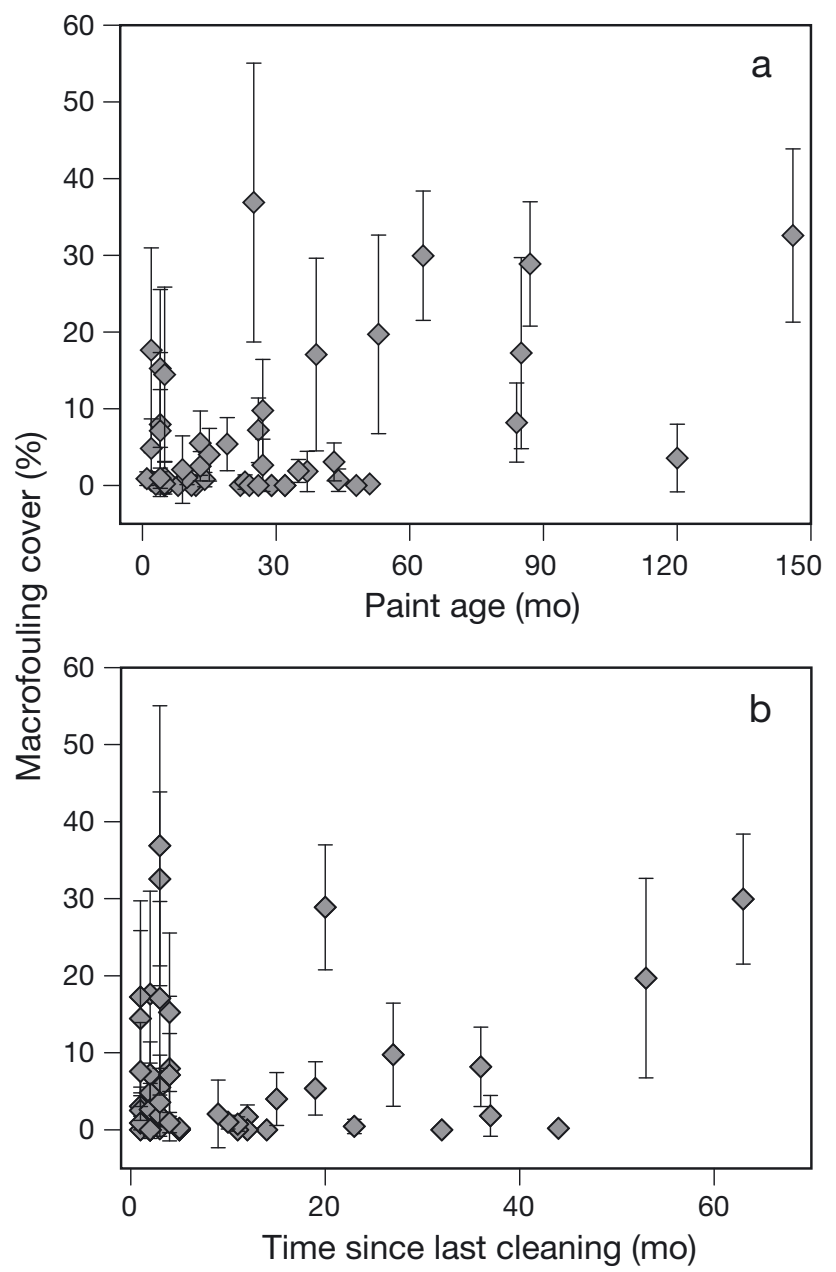

Fig. 6. Biofouling extent in relation to bottom-paint age and time since cleaning. The mean percent cover $(+95 \% \mathrm{CI})$ of macrofouling (macroalgal and macrofaunal categories combined) per boat was plotted with (a) age of bottom-paint and (b) time since last cleaning. The timescale for each plot is in months

biofouling coverage ranging between 0 and $100 \%$. As time since cleaning increased ( $>9 \mathrm{mo}$ ), average biofouling extent increased; for vessels that reported hull cleaning 9 mo prior or longer, there was an apparent positive correlation between macrofouling cover and time $(\mathrm{r}=0.415)$, but this did not fall below the critical significance value $(\mathrm{p}>0.05)$.

There were also no trends in biofouling extent, richness, or composition in relation to boat usage ( $\mathrm{r}=$ $-0.283, p>0.05)$. One vessel that reported taking 50 trips within the Bay over the past 12 mo had 36\% cover of macroalgae and hydroids. Another vessel that reported 50 voyages had $0 \%$ macrofouling cover. Five of 7 vessels that reported traveling to outside locations (transient vessels) had less than $1 \%$ macrofauna and algal cover. Stern surveys revealed that 2 of these transient vessels that had taken several trips to other Cali- fornia bays were fouled with macroalgae, bryozoans (including Bugula neritina), solitary ascidians (including Ciona intestinalis), and sponges.

\section{Level of fouling}

LoF correlated significantly with biofouling percent cover and richness on hulls $(\mathrm{n}=72 ; \mathrm{r}=0.742$ for cover and 0.510 for richness, $p<0.001)$. The proportional contribution of boats in each LoF category varied significantly among the 6 marinas (Fig. $7 ; \chi^{2}=232.48$, df $=$ $25, \mathrm{p}<0.001)$. Antioch marina, which was the most heavily freshwater-influenced site among the 6 marinas sampled, had the lowest proportion of Level 5 vessels. Oyster Point and San Leandro marinas in the South Bay had the highest proportions of vessels with Level 5 biofouling. Level 5 was the second most commonly assigned level, with $22 \%$ of vessels overall. Level 2 , i.e. the level at which macrofouling species become evident on the 6 point scale, was the most common level (27\%) among all vessels sampled, and $73 \%$ of all vessels surveyed had Level 2 biofouling or greater. Loch Lomond marina had the highest proportion of vessels with Level 0, but Antioch had the highest proportion (44\%) of vessels with Level 1 biofouling or less (i.e. no macrofouling species present).

Finally, comparisons across studies (Table 3) revealed that a higher proportion of SF Bay vessels had heavier biofouling than vessels arriving in New Zealand (Floerl et al. 2005a) and resident in Scotland (Ashton et al. 2006). The percentages of vessels surveyed in New Zealand and Scotland with Levels 1 and 2 (i.e. probably without any macrofouling) were 54.5 and $41.2 \%$, respectively, whereas only $26.7 \%$ of vessels in SF Bay were categorized as such. The most heavily fouled vessels (Level 5) amounted to $21.6 \%$ of the SF Bay sample population, but the proportions of Level 5 vessels arriving in New Zealand (4.2\%) and based in Scotland $(9.6 \%)$ were much lower.

\section{DISCUSSION}

Recreational boating is an important feature of coastal environments that has grown dramatically in the last 4 decades. Minchin et al. (2006) highlighted the coupled increases in numbers of boats and marina space to accommodate them; for example, there has been an 11-fold increase in marinas in Queensland, Australia, while boats now number in the tens to hundreds of thousands in many coastal regions. The scale of maritime boating in SF Bay is similarly large, with over 150000 boats registered in this region (California State University Sacramento Foundation 2002). Our 

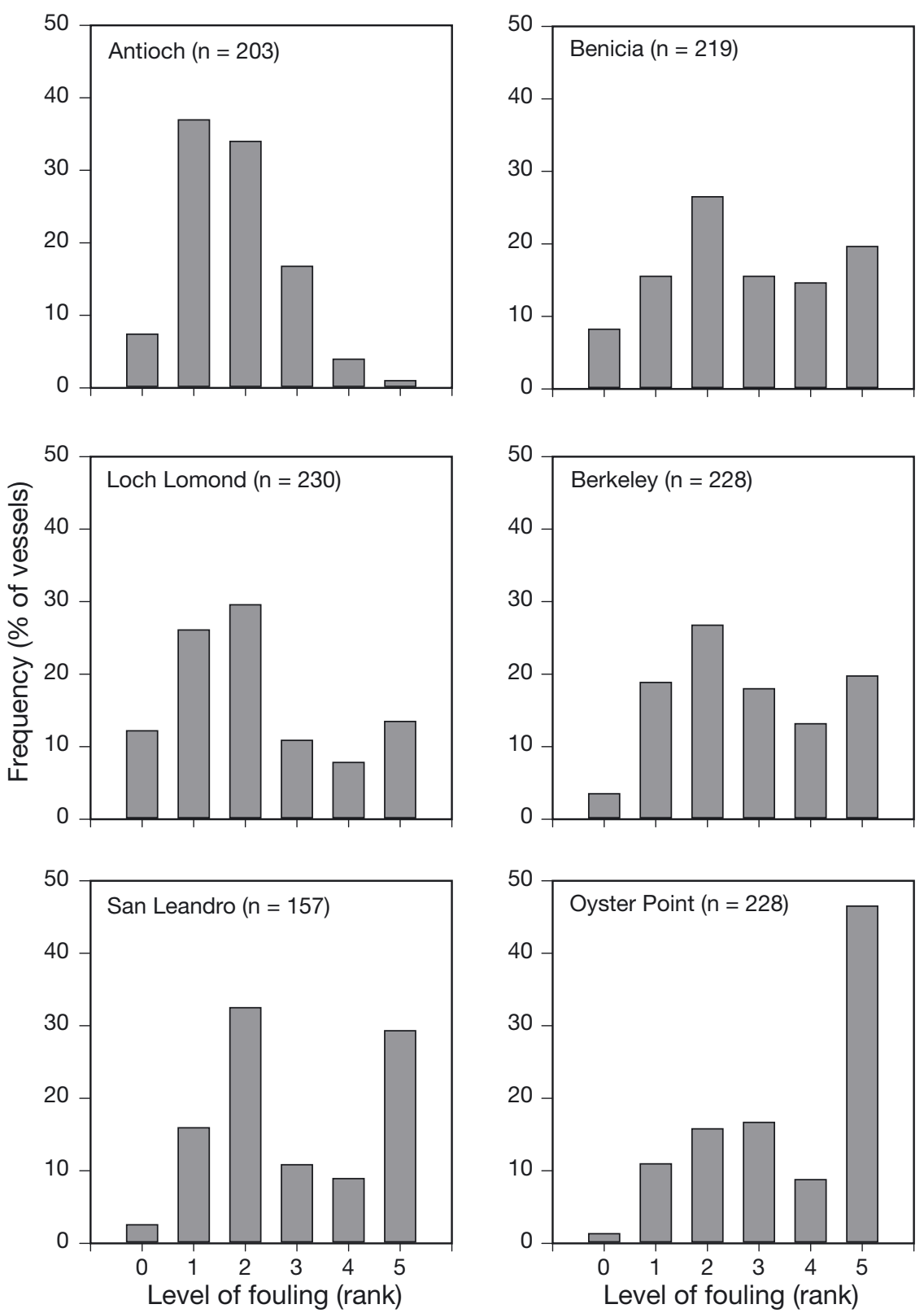

Fig. 7. Level of fouling (LoF) on boats among marinas. The frequency of boats in each LoF rank is shown as a percent of the total number of boats sampled for each of 6 marinas. The numbers of boats sampled in each marina are indicated in the plots

data suggest that this is important for movements of species because: (1) the Bay is highly invaded and is an important focal point for interactions between NIS and vectors; (2) localized within-Bay spread of species via boats is likely to be very frequent and sometimes involve heavily fouled vessels with dense assemblages of NIS; (3) this increases opportunities for species to interface with more recreational boats, commercial vessels, and other vectors to create a 'ratchet effect' of vector events; and (4) populations of NIS are likely to spread from SF Bay to other coastal sites via recreational boats and other vectors.
The richness of SF Bay's and North America's marine and estuarine non-native species is heavily influenced by biofouling community organisms (Cohen \& Carlton 1995, Fofonoff et al. 2003). The distributions of these biofouling species are strongly associated with marinas and other maritime structures (Ruiz et al. 2009). Biofouling on recreational vessels therefore represents a link between a very diverse community of source populations of NIS in SF Bay and vector activity that may inadvertently disperse them (including a high incidence of in-water cleaning [91\% of cleaning events] that may provide a mechanism for sessile organisms to 
Table 3. Comparison of level of fouling (LoF) ranks among studies. The frequency ( $\%$ of all vessels surveyed) of LoF ranks from vessels at 4 marinas in New Zealand (Floerl et al. 2005a), 10 marinas in Scotland (Ashton et al. 2006), and the 6 marinas in the present study are shown

\begin{tabular}{|lccc|}
\hline \multicolumn{4}{|c|}{ Observed frequency of LoF ranks (\% of vessels) } \\
$\begin{array}{l}\text { Fouling } \\
\text { rank }\end{array}$ & $\begin{array}{c}\text { Floerl et al. } \\
\text { (2005a) }\end{array}$ & $\begin{array}{c}\text { Ashton et al. } \\
(2006)\end{array}$ & $\begin{array}{c}\text { Present } \\
\text { study }\end{array}$ \\
\hline 0 & 10.6 & 4.8 & 6.0 \\
1 & 43.9 & 36.4 & 20.7 \\
2 & 18.0 & 23.2 & 27.1 \\
3 & 13.2 & 15.6 & 14.9 \\
4 & 10.1 & 10.4 & 9.6 \\
5 & 4.2 & 9.6 & 21.6 \\
& $\mathrm{n}=189$ & $\mathrm{n}=866$ & $\mathrm{n}=1265$ \\
\hline
\end{tabular}

disperse from vessel hulls). Similarly, the Bay may also act as a destination for NIS from other locations if visiting craft bring new species to the Bay. A recent study documented the northward spread of the introduced kelp Undaria pinnatifida from southern California into SF Bay and the recreational boating vector's probable role in it (Zabin et al. 2009). Studies from elsewhere have also shown that the vector warrants greater attention (Floerl \& Inglis 2005, Mineur et al. 2008, Darbyson et al. 2009), particularly since the most effective strategy for marine NIS management is incursion prevention (Carlton \& Ruiz 2003).

Within SF Bay, variation in biofouling among vessels and among marinas was substantial, which is a feature of recreational boat hull biofouling studies to date (Floerl \& Inglis 2005, Floerl et al. 2005a, Ashton et al. 2006). Similarly, boats themselves have uneven distributions of organisms among hull locations and stern running gears. A combination of site differences (e.g. in salinity), vessel maintenance practices, and boat usage contributes to these patterns. Movements solely within the Bay were also a dominant feature of boater behavior ( $76 \%$ of questionnaire respondents) increasing the likelihood of vector activity and species redistributions within the Bay. Of course, differences among marinas in species occurrences point to a differential vector risk from boats departing from each marina. For example, vessels at Antioch and Benicia marinas (freshwater sites) are likely to be low-risk donor sites compared to other marinas. Situating new marinas in low salinity or freshwater areas would likely be an effective strategy for reducing species transfers. Similarly, vessels visiting freshwater marinas are likely to reduce the amount of live marine organisms on submerged surfaces through osmotic shock. It was notable, however, that several boats sampled in Benicia marina were fouled with the non-native bryozoan Membranipora chesapeakensis (formerly Conopeum chesapeakensis) and may act as transfer mechanisms for the spread of this spatially-restricted species, populations of which are known from large ships nearby (in Suisun Bay; Davidson et al. 2008).

Despite differences in biofouling extent among transect depths, the LoF ranking scheme was a good indicator of biofouling extent (percent cover) on vessels in SF Bay (correlation r-value $=0.742$ ). While not a perfect predictor of biofouling extent (or richness or identity), this tool could prove effective as a quick and inexpensive method for broad-scale monitoring of vessels for managers (Floerl et al. 2005a). The frequency of LoF rank-5 vessels was much higher in SF Bay $(21.6 \%$, all 6 marinas combined) than for vessels examined in New Zealand (4.2\%, Floerl et al. 2005a) and Scotland (9.6\%, Ashton et al. 2006). The data of Floerl et al. (2005a) were derived from international arrivals to New Zealand only, so lower biofouling of those vessels compared to the primarily local or regional vessels sampled in SF Bay is probably a genuine function of recent long-distance voyages, higher vessel usage, and more regular and recent maintenance. Vessels in Scotland were of international and domestic origin, and there was no suggestion that the majority were not boats of local marina tenants, similar to our study of SF Bay boats. A host of factors probably contribute to the higher prevalence of highly fouled vessels in SF Bay, possibly including differential water movements, whereby enclosed marinas (in enclosed bays) allow greater and faster fouling accumulation than marinas on more open coasts (e.g. Floerl \& Inglis 2003).

The importance of secondary spread of NIS is particularly relevant to SF Bay because of its status as the most invaded bay in the region. Hub-and-spoke models of NIS spread have been well described in coastal marine systems (Carlton 1996, Floerl \& Inglis 2005, Floerl et al. 2009), and many NIS on the Pacific coast were first recorded in SF Bay (Ruiz et al. in press). This suggests the possibility of SF Bay as the hub for smaller systems in the region (Wasson et al. 2001, Sytsma et al. 2004, Ruiz et al. in review), and recreational boats have been implicated in NIS transfers. Wasson et al. (2001) showed that recreational craft are likely to have transferred several (many) of the NIS that occur in Elkhorn Slough (south of SF Bay). As a result, the recreational boat vector in the west coast region is more likely to engage in secondary spread, while commercial vessels transfer species from farther afield (Davidson et al. 2009). In contrast, locations like New Zealand (and other oceanic islands) are concerned with primary long-distance introductions from sailing boats entering their waters (Godwin et al. 2004, Floerl et al. 2005a).

Minchin et al. (2006) identified 3 categories of recreational vessels that posed different risks as vectors of 
NIS. One category included vessels that travel irregularly on short trips within $100 \mathrm{~km}$ of their home marina and may carry biofouling agents. This is generally the largest group of boaters in most locations, but the authors suggested that these vessels probably do not spread NIS to any great extent. Another smaller group of competitive racing yachts were also considered low risk because they are generally very well maintained and so accumulate little or no biofouling. The third group, the smallest of the 3 but the greatest threat on a per-vessel basis, included yachts that travel long distances (between countries or across seas) and may spend significant durations of time at several overseas ports.

Using a similar rationale, the preliminary results from this pilot study, discussions with marina operators, and other sources (e.g. California State University Sacramento Foundation 2002), we suggest that 6 categories of vessels (Table 4) are appropriate to SF Bay (and probably other sites). The categories include vessels that pose a vector threat because of regional and international voyage patterns, similar to Minchin et al. (2006). There are also vessel groups that have contrasting reasons for similarly low risk levels, such as heavily fouled vessels with very limited movements (Categories A and B in Table 4) and well traveled vessels with minimal biofouling accumulation (Category C).
A seventh category, involving overland (trailer) transport, is another important component of vector risk from recreational boats, but is associated with freshwater systems more than marine ones (e.g. implicated in spreading quagga mussels to western US states; Stokstad 2007). Each category was represented by at least 1 vessel in our study (e.g. the vessel that recently arrived from Peru would fit category F, see Table 4), but the largest group represented localized traffic (Category A, with $76 \%$ of questionnaire respondents), which indicates a high risk of anthropogenic NIS spread within the Bay. Such a framework could be used for management or outreach to target risky vessels with respect to NIS transfers (e.g. more regular hauling out or hull cleaning prior to voyages).

Management strategies for reducing NIS spread by recreational boat traffic in the USA have not been discussed or developed to any great extent. Indeed, recreational vessel arrivals are not widely monitored throughout the world for species incursions (Floerl et al. 2005a). In Europe, Mineur et al. (2008) suggested that screening or management efforts to prevent algal NIS incursions from leisure boats were not warranted (based on vessels they had sampled). However, a pattern is emerging against this '0-management' approach. For example, Floerl et al. (2005a) noted that monitoring in northern Australia over a 4 yr period intercepted 30

Table 4. Categorizing recreational vessels according to relative nonindigenous species (NIS) vector risk. Six categories of San Francisco (SF) Bay vessels were identified (A to F) based on travel patterns, biofouling extent, and relative risk of NIS transfers.

The groups are ranked in size from 1 (largest, most common) to 6 (smallest, least common). LoF: level of fouling

\begin{tabular}{|c|c|c|c|c|c|}
\hline $\begin{array}{l}\text { Cate- } \\
\text { gory }\end{array}$ & $\begin{array}{l}\text { Size of } \\
\text { group }\end{array}$ & $\begin{array}{l}\text { Typical voyage } \\
\text { frequency }\end{array}$ & $\begin{array}{l}\text { Voyage distance/ } \\
\text { destinations }\end{array}$ & $\begin{array}{l}\text { Biofouling (typical } \\
\text { LoF ranking) }\end{array}$ & Vector threat \\
\hline A & 1 & $\begin{array}{l}12 \text { to } 24 \text { trips } \\
\text { annually }\end{array}$ & $\begin{array}{l}\text { All voyages } \\
\text { within SF Bay }\end{array}$ & $\begin{array}{l}\text { Variable } \\
\text { (Levels } 0 \text { to 5) }\end{array}$ & $\begin{array}{l}\text { Very low, restricted to } \\
\text { concerns regarding species } \\
\text { transfers within SF Bay }\end{array}$ \\
\hline B & 2 & $\begin{array}{l}\text { Vessels remain } \\
\text { moored at home } \\
\text { marinas for months } \\
\text { or indefinitely }\end{array}$ & No voyages & $\begin{array}{l}\text { Extremely heavy } \\
\text { (Level 5) }\end{array}$ & $\begin{array}{l}\text { No NIS risk unless stochastic } \\
\text { movement occurs (e.g. when } \\
\text { sold), which may pose a } \\
\text { significant threat }\end{array}$ \\
\hline $\mathrm{C}$ & 3 & $\begin{array}{l}\text { Coinciding with } \\
\text { competitive races }\end{array}$ & $\begin{array}{l}\text { Local, regional, and } \\
\text { international }\end{array}$ & $\begin{array}{l}\text { Low } \\
\text { (Levels } 0 \text { to } 1 \text { ) }\end{array}$ & $\begin{array}{l}\text { Very low because vessels are } \\
\text { very well maintained, } \\
\text { including niche areas }\end{array}$ \\
\hline $\mathrm{D}$ & 4 & $\begin{array}{l}2 \text { to } 12 \text { trips, usage } \\
\text { skewed toward } \\
\text { summer months }\end{array}$ & $\begin{array}{l}\text { Within SF Bay and } \\
\text { within } 100 \mathrm{~km} \text { along } \\
\text { the adjacent outer } \\
\text { coastline }\end{array}$ & $\begin{array}{l}\text { Variable (Levels } 0 \text { to } 5 \text { ), } \\
\text { but likely to have lower } \\
\text { fouling extent than } \\
\text { Category A vessels }\end{array}$ & $\begin{array}{l}\text { Low risk of primary introductions, } \\
\text { moderate and possible high threat } \\
\text { of NIS secondary spread depending } \\
\text { on vessel maintenance }\end{array}$ \\
\hline E & 5 & 1 or 2 trips annually & $\begin{array}{l}\text { Voyages to other west } \\
\text { coast regions (Mexico, } \\
\text { southern California, } \\
\text { Pacific NW, British } \\
\text { Columbia, Alaska) }\end{array}$ & $\begin{array}{l}\text { Variable (Levels } 0 \text { to } 5 \text { ), } \\
\text { but likely to have lower } \\
\text { fouling extent than } \\
\text { Category A and D } \\
\text { vessels }\end{array}$ & $\begin{array}{l}\text { Variable; good hull maintenance } \\
\text { reduces the risk, but arrivals after } \\
\text { long port durations pose a high risk } \\
\text { significant threat of NIS donation } \\
\text { from SF Bay }\end{array}$ \\
\hline $\mathrm{F}$ & 6 & Occasional arrivals & $\begin{array}{l}\text { Non-racing overseas } \\
\text { arrivals, or foreign } \\
\text { return trips by SF Bay } \\
\text { residents }\end{array}$ & $\begin{array}{l}\text { Variable (Levels } 0 \text { to } 5 \text { ) } \\
\text { but generally low } \\
\text { because of maintenance } \\
\text { and long voyages }\end{array}$ & $\begin{array}{l}\text { Low to high depending on fouling } \\
\text { level, voyages from overseas and } \\
\text { niche area fouling increase the } \\
\text { risk of primary invasions }\end{array}$ \\
\hline
\end{tabular}


hull-mediated incursions of species that are nonindigenous to that region. Moreover, recreational vessels arriving from overseas to Australia are now recommended to apply antifouling paint within $1 \mathrm{yr}$ prior to arrival, and/or clean just prior to arrival, or they should be removed from the water and cleaned upon arrival (Australian Quarantine and Inspection Service 2007). Australia is moving towards mandatory application of this (or a similar) management scheme, while New Zealand is adopting a comparable approach (Biosecurity New Zealand 2007). Other examples of vector management of recreational boats occurred after outbreaks of marine pests in Prince Edward Island, Canada (see www.cbc.ca/canada/prince-edward-island/story/ 2007/10/02/invasive-species.html) and Darwin, Australia (Field 1999). Invasive tunicates (including Styela clava) and black striped mussels Mytilopsis sallei, at each site respectively, required emergency control and quarantine measures placed on leisure craft to prevent their spread.

Further evaluation of recreational boating vectors within the larger northeast Pacific region should focus on transient vessels, including those that may contribute to SF Bay's status as a donor site for secondary spread. The high numbers of highly fouled vessels (at the highest point on the LoF ranking system) were unlikely to be transient, especially outside of the Bay. However, we were unable to sample many transient vessels that voyage outside the Bay, while the few we did sample had macrobiota on stern surfaces, including NIS. Without these data, the risk of introduction from vessels engaged in coastwise voyages cannot be assessed. These data would inform policymakers and fill critical information gaps about a vector that has long been under-appreciated in comparison to commercial ships.

Acknowledgements. We are grateful to R. Draheim and C. Simkanin for their contributions to project initiation and development. We thank J. Leonard of the Hawaii Department of Lands and Natural Resources and S. Altman for helpful discussions and assistance in the field. We also thank B. Proctor of the US Fish \& Wildlife Service for helpful advice and comments. The Human Subjects Research Review Committee at Portland State University provided a timely review and approval of our questionnaire for this project. This project was funded by the US Fish \& Wildlife Service through the Western Regional Panel on Aquatic Invasive Species.

\section{LITERATURE CITED}

Ashton G, Boos K, Shucksmith R, Cook E (2006) Risk assessment of hull fouling as a vector for marine non-natives in Scotland. Aquat Invasions 1:214-218

Australian Quarantine and Inspection Service (2007) Keep your vessel clean to assist quarantine: what you can do before you arrive in Australian waters. Commonwealth of Australia, Canberra
Biosecurity New Zealand (2007) Don't bring hitchhikers to New Zealand. Ministry of Agriculture and Forestry, Biosecurity New Zealand, Wellington

Cadotte MW, Fukami T, McMahon SM (2006) Linking scale dependent processes in invasions. In: Cadotte MW, McMahon SM, Fukami T (eds) Conceptual ecology and invasion biology: reciprocal approaches to nature. Springer, Dordrecht, p 483-494

California State University Sacramento Foundation (2002) California boating facilities needs assessment. Regional boaters and boating facilities, Vol 2. California Department of Boating and Waterways, Sacramento, CA

Carlton JT (1979) History, biogeography, and ecology of the introduced marine and estuarine invertebrates of the Pacific Coast of North America. PhD dissertation, University of California, Davis, CA

Carlton JT (1985) Transoceanic and interoceanic dispersal of coastal marine organisms: the biology of ballast water. Oceanogr Mar Biol Annu Rev 23:313-371

Carlton JT (1996) Pattern, process, and prediction in marine invasion ecology. Biol Conserv 78:97-106

Carlton JT, Ruiz GM (2003) Vector science and integrated vector management in bioinvasion ecology: conceptual frameworks. In: Ruiz GM, Carlton JT (eds) Invasive species: vectors and management strategies. Island Press, Washington, DC, p 36-58

Chilton C (1910) Note on the dispersal of marine Crustacea by means of ships. Trans Proc R Soc N Z 43:131-133

Cohen AN, Carlton JT (1995) Biological study of nonindigenous aquatic species in a United States estuary: a case study of the biological invasions of the San Francisco Bay and Delta. Report to US Fish and Wildlife Service, Washington, DC

Cohen AN, Carlton JT (1998) Accelerating invasion rate in a highly invaded estuary. Science 279:555-558

> Cohen AN, Harris LH, Bingham BL, Carlton JT and others (2005) Rapid assessment survey for exotic organisms in southern California bays and harbors, and abundance in port and no-port areas. Biol Invasions 7:995-1002

Coutts ADM, Taylor MD (2004) A preliminary investigation of biosecurity risks associated with biofouling on merchant vessels in New Zealand. NZ J Mar Freshw Res 38:215-229

> Darbyson E, Locke A, Hanson JM, Willison JHM (2009) Marine boating habits and the potential for spread of invasive species in the Gulf of St. Lawrence. Aquat Invasions 4:87-94

> Davidson IC, McCann LD, Fofonoff PW, Sytsma MD, Ruiz GM (2008) Assessing the potential for hull-mediated species transfers by obsolete ships on their final voyages. Divers Distrib 14:518-529

Davidson IC, Brown CW, Sytsma MD, Ruiz GM (2009) The role of containerships as transfer mechanisms of marine biofouling species. Biofouling 25:645-655

DeFelice RC (1999) Fouling marine invertebrates on the floating dry dock USS Machinist in Pearl Harbor prior to its move to Apra Harbor, Guam. Report to US Fish and Wildlife Service, Honolulu, HI

Dytham C (2003) Choosing and using statistics: a biologist's guide, 2nd edn. Blackwell Publishing, Oxford

Field D (1999) Disaster averted? Black striped mussel outbreak in northern Australia. Fish Farming Int 26:30-31

Floerl O, Inglis GJ (2003) Boat harbour design can exacerbate hull fouling. Austral Ecol 28:116-127

> Floerl O, Inglis GJ (2005) Starting the invasion pathway: the interaction between source populations and human transport vectors. Biol Invasions 7:589-606

Floerl O, Inglis GJ, Hayden BJ (2005a) A risk-based predic- 
tive tool to prevent accidental introductions of nonindigenous marine species. Environ Manag 35:765-778

Floerl O, Inglis GJ, Marsh HM (2005b) Selectivity in vector management: an investigation of the effectiveness of measures used to prevent transport of non-indigenous species. Biol Invasions 7:459-475

Floerl O, Inglis GJ, Dey K, Smith A (2009) The importance of transport hubs in stepping-stone invasions. J Appl Ecol 46: $37-45$

Fofonoff PW, Ruiz GM, Steves B, Carlton JT (2003) In ships or on ships? Mechanisms of transfer and invasion for nonnative species to the coasts of North America. In: Ruiz GM, Carlton JT (eds) Invasive species: vectors and management. Island Press, Washington, DC, p 152-182

Foster BA, Willan RC (1979) Foreign barnacles transported to New Zealand on an oil platform. NZ J Mar Freshw Res 13:143-149

Galil BS (2008) The marine caravan - the Suez Canal and the Erythrean invasion. In: Gollasch S, Galil BS, Cohen AN (eds) Bridging divides: maritime canals as invasion corridors. Springer, Dordrecht, p 207-301

Godwin LS, Eldredge LG, Gaut K (2004) The assessment of hull fouling as a mechanism for the introduction and dispersal of marine alien species in the main Hawaiian Islands. Bishop Mus Tech Rep No 28. Bishop Museum, Honolulu, HI

Gollasch S (2002) The importance of ship hull fouling as a vector of species introductions into the North Sea. Biofouling 18:105-121

Hayden HS, Blomster J, Maggs CA, Silva PC, Stanhope MJ, Waaland JR (2003) Linnaeus was right all along: Ulva and Enteromorpha are not distinct genera. Eur J Phycol 38: 277-294

Lee JE, Chown SL (2009) Temporal development of hullfouling assemblages associated with an Antarctic supply vessel. Mar Ecol Prog Ser 386:97-105

Minchin D, Floerl O, Savini D, Occhipinti-Ambrogi A (2006) Small craft and the spread of exotic species. In: Davenport J, Davenport JL (eds) The ecology of transportation: managing mobility for the environment. Springer, Dordrecht, p 99-118

Mineur F, Johnson MP, Maggs CA (2008) Macroalgal intro-

Editorial responsibility: Francesco Patti,

Ischia, Italy ductions by hull fouling on recreational vessels: seaweeds and sailors. Environ Manag 42:667-676

Puth LM, Post DM (2005) Studying invasion: Have we missed the boat? Ecol Lett 8:715-721

> Ruiz GM, Fofonoff PW, Carlton JT, Wonham MJ, Hines AH (2000) Invasion of coastal marine communities in North America: apparent patterns, processes and biases. Annu Rev Ecol Syst 31:481-531

Ruiz GM, Freestone AL, Fofonoff PW, Simkanin C (2009) Habitat distribution and heterogeneity in marine invasion dynamics: the importance of hard substrate and artificial structure. In: Wahl M (ed) Marine hard bottom communities. Ecological Studies 206. Springer-Verlag, Berlin, p 321-332

Ruiz GM, Fofonoff PW, Steves B, Foss SF, Shiba SN (in press) Marine invasion history and vector analysis of California: a hotspot for western North America. Divers Distrib

Simkanin C, Davidson I, Falkner M, Sytsma M, Ruiz G (2009) Intra-coastal ballast water flux and the potential for secondary spread of non-native species on the US West Coast. Mar Pollut Bull 58:366-374

Stokstad E (2007) Feared quagga mussel turns up in western United States. Science 315:453 doi:10.1126/science.315. 5811.453

Sytsma MD, Cordell JR, Chapman JW, Draheim RC (2004) Lower Columbia River aquatic nonindigenous species survey 2001-2004, Final Technical Report. Report to the United States Coast Guard and the United States Fish and Wildlife Service, Washington, DC

Visscher JP (1928) Nature and extent of fouling on ships' bottoms. Bull Bur Fish 43:193-252

> Wasson K, Zabin CJ, Bedinger L, Diaz MC, Pearse JS (2001) Biological invasions of estuaries without international shipping: the importance of intraregional transport. Biol Conserv 102:143-153

WHOI (Woods Hole Oceanographic Institute) (1952) Marine fouling and its prevention. US Naval Institute, Annapolis, MD

> Zabin CJ, Ashton GV, Brown CW, Ruiz GM (2009) Northern range expansion of the Asian kelp Undaria pinnatifida (Harvey) Suringar (Laminariales, Phaeophyceae) in western North America. Aquat Invasions 4:429-434

Submitted: August 25 2010; Accepted: October 14, 2010

Proofs received from author(s): December 7, 2010 